\title{
Physical Neglect has become the Most Common Category of Child Neglect in Sri Lanka
}

\author{
Himalshi Serasinghe \\ Department of Philosophy, University of Kelaniya, Sri Lanka
}

\begin{abstract}
Neglecting the child could be a factor for generating mentally and physically ill people all around the world. Child neglect has simply defined the avoidance of primary care and failure to provide basic facilities including food, clothing, healthcare, education for the child by their parents or guardian. Child neglect considers as the most prevalent category of child abuse not only in Sri Lanka but also worldwide. Child welfare specialists form common categories of neglect including physical neglect, medical neglect, inadequate supervision, environmental neglect, emotional neglect, educational neglect. Though previous researchers have identified all the above categories of child neglect, there is no research have done to identify the most common category of child neglect in the Sri Lankan Context. The objective of this study is to identify the most common category of child neglect in Gampaha district, western province, Sri Lanka. Primary data were collected using mixed research method. Distributed structured questionnaires $(\mathrm{N}=134)$ and conducted semi-structured interviews $(\mathrm{N}=10)$ from neglected children who were reported in Gampaha District, Sri Lanka. The researcher used descriptive statistics, factor analysis, and content analysis for analyzing purposes. The findings show the physical neglect is the most common type of child neglect while the cognitive neglect type has the lowest respondents. Supervision and emotional neglect indicated third and fourth places respectively. Government should take necessary action in assigning relevant officers including Child Rights Promoting Officers, Social Workers, Gramasewaka, and active officers for the relevant committees in order to spot children who are neglected by their families.
\end{abstract}

Keywords: Child abuse, Child Neglect, Child Neglect Categories, Commonest child neglect category

\section{INTRODUCTION}

$\mathrm{S}$ i Lanka is home for more than 20 million people. Sri Lanka is a multi-ethnic and multi-religious country with residents including Sinhalese (the majority), Sri Lankan Tamils and Tamil of Indian origin, Moors, Burghers and Malays (Seneviratne \& Silva, 2014). Children below the age of 18 years are 5.836 million. Sri Lanka has a set of service provision to develop its children and this includes free medical care, free education, food sponsorships and various welfare equally (Seneviratne et al., 2014). However, some experience difficulties in accessing the said facilities due to the neglect of their parents or guardians.

According to the child right convention of Sri Lanka, every individual below the age 18 years is a child and every child needs attention and care from the society (Upali \& Fonseka, 2017). National Child Protection Authority (NCPA) being the main state institution that provides services to children, reports annually about their work and situation of children in the country. It's Annual Reports on 'cruelty to children' as the highest complained type of abuse from 2010 to 2019 and 'lack of care and protection' as the second highest reported abuse from 2010 to 2011. The 'inability to give compulsory education to the child' was the second highest issue reported 2012 to 2019. The 'Neglect of children' was classified as the fourth highest reported abuse during the 2012 to 2019 period except 2016 and 2018. Cruelty to children, lack of care and protection, inability to provide compulsory education to the child are some of aspects of the child neglect (Child Welfare Information Gateway, 2011).

Review of statistics on child neglect in Sri Lanka reveals that more than $12 \%$ of the children aged between 5 and 14 had to stop their compulsory education because they were engaged in undefined occupations in the informal sector (Upali \& Fonseka, 2017). Child abuse and neglect are the most common categories of child maltreatment in Sri Lanka. Further, child neglect is the major aspect of abuse and it has increased over the years that results in more damage to children in comparison to other types of abuses (Harrington \& Ting, 2002). Furthermore, child neglect is gradually developing into child protection issue in Sri Lanka (Serasinghe, 2021).

Child neglect may involve a parent or guardian failing to provide sufficient food, clothing and shelter, protect a child from physical and emotional harm or vulnerability, sufficient supervision, access to proper medical care or treatment (Wilkinson 2017). There are various types of child neglect which can be identified in the literature: Educational Neglect, Medical Neglect, Physical Neglect, Environmental Neglect, Emotional Neglect and Inadequate Supervision and so on (Ben-David, 2016).

Definitions of physical neglect elaborate the failure to provide basic physical needs and supervision to the child (Cort et al., 2011). In addition, child physical neglect has also been defined by various authors based on various perspectives. The literature review found aspects of physical neglect; it includes, (i) abandonment: neglect of a child without arranging his reasonable care or supervision (ii) expulsion: blatant refusal or custody such as permanent or indefinite expulsion of the child from home (iii) shuttling: a child is usually left in the protection of others for days or weeks at a time and this situation occurs probably due to the unwillingness of the parent or the caregiver to continue the 
custody (iv) nutritional neglect: a child is malnourished or frequently hungry for a long time which can sometimes result in poor growth, (v) clothing neglect: lack of appropriate clothes for the child (Harrington \& Ting, 2002 \& Putnam, 2001).

Inadequate supervision includes a number of behaviors: (1) lack of appropriate supervision; (2) exposure to the hazards, for instance (i) safety hazards: poisons, small objects, electrical wires, stairs (ii) smoking: second hand smoke, particularly for children with asthma or other lung problems (iii) guns and other weapons: guns that are kept in the house that are loaded and not locked up or are in reach of children (iv) unsanitary household conditions: insect infection, lack of clean water (3) Inappropriate caregivers: a child in the care of someone who is unable or should not be trusted to provide care for the child (Harrington, Zuravin, Depanfilis, Ting, \& Dubowitz, 2002).

Environmental neglect is the lack of environmental or neighborhood safety opportunities and properties. Children's safety and protection from risks are the major concerns of the child protective services. A wide view of neglect connects with the environmental conditions linking neighborhood factors. Particularly, harmful impact of dangerous neighborhoods on children's development, mental health and child maltreatment (Ben-David, 2016).

Emotional neglect is the lack of care experience for children when their parents or guardian fail to provide background or environments conducive to their feelings such as being wanted, loved and worthy (Parkinson, Bromfield, Mcdougall, \& Salveron, 2017). According to Polonko (2006) emotional neglect is more harmful than other types of neglect as well as it has severe long lasting consequences than physical neglect. Further, emotional neglect frequently occurs with other forms of neglect or abuse including (i) inadequate nurturing or affection (ii) permitted drug or alcohol abuse (iii) isolation (Goldman \& Salus, as cited in Carter \& Myers, 2007). In addition, emotional neglect is described as an absence of parent child interactions including not being hugged, validated or not expressing their love feelings to the child (Parkinson et al., 2017). Emotional neglect frequently occurs with the other forms of neglect or abuse which may be easier to recognize ( Baker, 2010 as cited in Wilkinson, 2017).

According to a report published by the National Child Protection Authority (NCPA) from 2010 to 2018, than any other part of Sri Lanka, children who live in Western Province were reported to have received less attention in terms of basic human needs. Precisely, 'cruelty to children' and 'not giving compulsory education' have consecutively ranked first or second place among the neglect categories, which has turned out to be a controversial issue. Unfortunately, neglect is unreported and has been given fewer attention compared to other types of abuses (Serasinghe, 2021). Further, child neglect is the main aspect of abuse and it has improved over the years that results in more harm to children in comparison to other types of abuses (Harrington et al., 2002 Cited in
Serasinghe, 2021). However, with all these reports and information, it is regretful to state that only a handful of research studies have been conducted with regard to child neglect. Since it was evident that child neglect is a continuously prevailing condition in Sri Lanka, it is rare to find studies related to the most common category of child neglect in Sri Lankan context. Because by researching, problems can be tackled and necessary measures can be taken accordingly. Therefore is it questionable as to why less attention is given to a serious existing issue in the country. Consequently, this study will contribute to fill in this gap in the research and policy making that benefits the children in the country.

\section{METHODOLOGY}

The researcher used mixed research method by using both qualitative and quantitative data. Secondary data method was used to interpret the results such as published researched articles, national and international documents. The population was children who were victims of child neglect in Gampaha District, Western Province, Sri Lanka. Further, the researcher used snowballing method for collecting data and the total sample size was 134 children.

The structured questionnaire was developed in English and was translated into Sinhala; hence every respondent in the sample population was able to understand the questions. The questionnaire consisted of two parts; the first part covered the demographic data of the respondents; the second part was on the type of neglect. The demographic part consisted of seven items such as gender, age, living area, number of siblings, religion, ethnicity, and level of education. As the second part of the questionnaire, researcher has used neglect scale developed by the (Straus, Kinard \& Williams, 1997). This scale consisted of 29 items which were divided into four major parts as physical neglect, emotional neglect, cognitive neglect, and supervision neglect. 134 questionnaires were distributed to neglected children who were reported in Gampaha District and conducted 10 semi-structured interviews with selected children aged between 12 and 18 and each interview took more than 45 minutes. This study used descriptive statistics, factor analysis and content analysis as the tools of analyzing.

\section{III . DATA PRESENATAION AND ANAYSIS}

\section{III.I Likert Scale Data}

Table I: Ferquency For Indicators Of Emotional Neglect Component

\begin{tabular}{|c|c|c|c|c|c|}
\hline \multicolumn{2}{|r|}{ Indictor } & \multirow[b]{2}{*}{1} & \multicolumn{3}{|c|}{$\begin{array}{l}\text { Number of } \\
\text { Responses to } \\
\text { Likert Scale }\end{array}$} \\
\hline & & & 2 & 3 & 4 \\
\hline EN1. & Paid no attention to me & 23 & 30 & 26 & 55 \\
\hline EN2. & Did not hug me & 25 & 29 & 13 & 66 \\
\hline EN3. & Ignored my feelings about things & 30 & 16 & 43 & 44 \\
\hline EN4. & Did things with me just for fun & 11 & 06 & 30 & 80 \\
\hline EN5. & $\begin{array}{l}\text { Were not proud when I succeeded in } \\
\text { something }\end{array}$ & 40 & 30 & 18 & 46 \\
\hline
\end{tabular}




\begin{tabular}{|c|c|c|c|c|c|}
\hline EN6. & $\begin{array}{c}\text { Forgot about things they were } \\
\text { supposed to do for me }\end{array}$ & 29 & 17 & 37 & 51 \\
\hline EN7. & Did not praise me & 31 & 23 & 32 & 48 \\
\hline EN8. & $\begin{array}{c}\text { Did not give me presents for my } \\
\text { birthday or holidays }\end{array}$ & 23 & 19 & 41 & 51 \\
\hline
\end{tabular}

According to Table 1 modes of the responses for most of the components is 4 (Strongly Agree), for the negative meaning indicators. It shows that most of the respondents had negative ideas on the indicators of emotional neglect.

TABLE II: Freqency For Indicators Of The Cognitive Neglect Component

\begin{tabular}{|c|c|c|c|c|c|}
\hline \multirow{2}{*}{\multicolumn{2}{|c|}{ Indictor }} & \multicolumn{4}{|c|}{$\begin{array}{c}\text { Number of } \\
\text { Responses to Likert } \\
\text { Scale }\end{array}$} \\
\hline & & 1 & 2 & 3 & 4 \\
\hline CN1 & $\begin{array}{l}\text { Did not help me with homework } \\
\text { when I needed help }\end{array}$ & 40 & 16 & 30 & 48 \\
\hline $\mathrm{CN} 2$ & $\begin{array}{l}\text { Did not help me when I had } \\
\text { trouble understanding something }\end{array}$ & 39 & 14 & 29 & 52 \\
\hline $\mathrm{CN} 3$ & Did not read books to me & 38 & 11 & 29 & 56 \\
\hline $\mathrm{CN} 4$ & $\begin{array}{l}\text { Did not show interest in my } \\
\text { grades in school }\end{array}$ & 24 & 16 & 40 & 53 \\
\hline $\mathrm{CN} 5$ & $\begin{array}{l}\text { Did not talk about things in the } \\
\text { news with me }\end{array}$ & 34 & 18 & 41 & 41 \\
\hline
\end{tabular}

According to the Table 2 modes of the responses for most of the components is 4 (Strongly Agree), for the negative meaning indicators. It shows that most of the respondents had negative perception on the indicators of cognitive neglect.

TABLE III: Frequncy For Indicators Of The Supervision Neglect Comonent

\begin{tabular}{|c|c|c|c|c|c|}
\hline \multirow{2}{*}{} & \multicolumn{4}{c|}{$\begin{array}{c}\text { Number of } \\
\text { Indictor }\end{array}$} & \multicolumn{3}{|c|}{\begin{tabular}{c} 
Responses to Likert \\
\cline { 3 - 6 }
\end{tabular}} & $\mathbf{1}$ & $\mathbf{2}$ & $\mathbf{3}$ & $\mathbf{4}$ \\
\hline SN1. & $\begin{array}{c}\text { Did not care if what I did was right } \\
\text { or wrong }\end{array}$ & 17 & 09 & 22 & 86 \\
\hline SN2. & $\begin{array}{c}\text { Left me alone without an adult when } \\
\text { I was too young for that }\end{array}$ & 28 & 24 & 25 & 56 \\
\hline SN3. & $\begin{array}{c}\text { Did not Want to know what I was } \\
\text { doing when I was not at home }\end{array}$ & 31 & 23 & 29 & 51 \\
\hline SN4. & $\begin{array}{c}\text { Did not care if I get into trouble in } \\
\text { school }\end{array}$ & 22 & 19 & 39 & 54 \\
\hline SN5. & $\begin{array}{c}\text { Did not interested in the kind of } \\
\text { friends I had }\end{array}$ & 21 & 08 & 39 & 66 \\
\hline SN6. & $\begin{array}{c}\text { Did not care if I did things like } \\
\text { shoplifting }\end{array}$ & 17 & 09 & 22 & 86 \\
\hline SN7. & $\begin{array}{c}\text { Put clear limits on what I was } \\
\text { allowed to do }\end{array}$ & 25 & 23 & 45 & 41 \\
\hline SN8. & $\begin{array}{c}\text { Did not worried about my getting } \\
\text { into trouble after school }\end{array}$ & 31 & 31 & 38 & 34 \\
\hline SN9. & $\begin{array}{c}\text { Did not interested in the kind of } \\
\text { friend I had }\end{array}$ & 22 & 26 & 48 & 38 \\
\hline
\end{tabular}

According to Table 3 modes of the responses for most of the indicators is 4 scale, which is 'strongly agree'. Mode value of indicators was 3 which was 'agree'. Accordingly, most of the respondents had negative perception on the indicators of supervision neglect.
Table IV: Frequncy For Indicators Of The Physical Neglect Component

\begin{tabular}{|c|c|c|c|c|c|}
\hline \multirow{2}{*}{} & \multicolumn{4}{|c|}{ Indictor } & \multicolumn{4}{|c|}{ Likert Scale } \\
\cline { 2 - 6 } & $\mathbf{1}$ & $\mathbf{2}$ & $\mathbf{3}$ & $\mathbf{4}$ \\
\hline PN1. & $\begin{array}{c}\text { I did not see a dentist when I needed } \\
\text { one }\end{array}$ & 21 & 08 & 30 & 75 \\
\hline PN2. & $\begin{array}{c}\text { Locked me out of the house on } \\
\text { purpose }\end{array}$ & 11 & 11 & 47 & 64 \\
\hline PN3. & $\begin{array}{c}\text { Made sure that I did not get enough } \\
\text { sleep }\end{array}$ & 42 & 20 & 12 & 60 \\
\hline PN4. & Did not give me clean clothes & 24 & 05 & 28 & 72 \\
\hline PN5. & $\begin{array}{c}\text { I did not see a doctor when I needed } \\
\text { one }\end{array}$ & 10 & 08 & 49 & 67 \\
\hline PN6. & Did not give me enough food to eat & 20 & 23 & 18 & 72 \\
\hline PN7. & $\begin{array}{c}\text { Did not give me enough clothes to } \\
\text { keep me warm }\end{array}$ & 24 & 05 & 28 & 72 \\
\hline
\end{tabular}

The Table 4 shows that modes of the responses for all of indicators is scale 4, which is 'strongly agree'. As per the responses, most of the respondents had negative ideas on the indicators of supervision neglect.

\section{III.II Score Estimation For Neglect Types}

The researcher constructed the indexes using the values given in above Likert Scale for each and every factor by using the factor score method.

\section{II.I Score Estimation For Emotional Neglect}

Table V: Communalities Results Of Confirmatory Factor Analysis For Emotional Neglect

\begin{tabular}{|c|c|c|}
\hline Emotional Neglect Indicator & ID & Communality \\
\hline Paid no attention to me & EN1 & 0.355 \\
\hline Did not hug me & EN2 & 0.636 \\
\hline Ignored my feelings about things & EN3 & 0.700 \\
\hline Did things with me just for fun & EN4 & 0.403 \\
\hline Were not proud when I succeeded in something & EN5 & 0.526 \\
\hline $\begin{array}{c}\text { Forgot about things they were supposed to do for } \\
\text { me }\end{array}$ & EN6 & 0.606 \\
\hline $\begin{array}{c}\text { Did not praise me } \\
\text { Did not give me presents for my birthday or } \\
\text { holidays }\end{array}$ & EN7 & 0.670 \\
\hline
\end{tabular}

According to the results shown in Table 5 the scores of each and every respondent for the emotional neglect factor can be calculated as below.

Emotional Neglect Score $=0.355(\mathrm{EN} 1)+0.636(\mathrm{EN} 2)+$ $0.700(\mathrm{EN} 3)+0.403(\mathrm{EN} 4)+0.526(\mathrm{EN} 5)+0.606(\mathrm{EN} 6)+$ $0.670(\mathrm{EN} 7)+0.467(\mathrm{EN} 8)$

E3 can be identified as the highly affected indicator for Emotional Neglect while E1 is less impacted when considering other indicators. 


\section{III.II.II Score Estimation For Supervision Neglect}

Table Vi: Communalities Results Of Confirmatory Factor Analysis For Supervision Neglect

\begin{tabular}{|c|c|c|}
\hline Supervision Neglect Indicator & ID & Communality \\
\hline Did not care if what I did was right or wrong & SN1 & 0.752 \\
\hline $\begin{array}{c}\text { Left me alone without an adult when I was too } \\
\text { young for that }\end{array}$ & SN2 & 0.700 \\
\hline $\begin{array}{c}\text { Did not want to know what I was doing when I } \\
\text { was not at home }\end{array}$ & SN3 & 0.334 \\
\hline Did not care if I get into trouble in school & SN4 & 0.712 \\
\hline Did not interested in the kind of friends I had & SN5 & 0.105 \\
\hline Did not care if I did things like shoplifting & SN6 & 0.204 \\
\hline Put clear limits on what I was allowed to do & SN7 & 0.628 \\
\hline $\begin{array}{c}\text { Did not worried about my getting into trouble } \\
\text { after school }\end{array}$ & SN8 & 0.498 \\
\hline Did not interested in the kind of friend I had & SN9 & 0.369 \\
\hline
\end{tabular}

According to the results shown in Table 6 the scores of each and every respondent for the reliability factor can be calculated as below.

Supervision Neglect Score $=0.752(\mathrm{SN} 1)+0.700(\mathrm{SN} 2)+$ $0.334(\mathrm{SN} 3)+0.712(\mathrm{SN} 4)$ $+0.105(\mathrm{SN} 5)+0.204$ $(\mathrm{SN} 6)+0.352(\mathrm{SN} 7)+$ $0.198(\mathrm{SN} 8)+0.369(\mathrm{SN} 9)$

The SN1 is the highly affected indicator for the Supervision Neglect, and SN5 is less impacted for the supervision neglect when compared to other indicators.

\section{III.II.III Score Estimation For Cognitive Neglect}

Table Vii: Communalities Results Of Confirmatory Factor Analysis For Cognitive Neglect

\begin{tabular}{|c|c|c|}
\hline Indicator & ID & Communality \\
\hline $\begin{array}{c}\text { Did not help me with homework when I } \\
\text { needed help }\end{array}$ & $\mathrm{CN} 1$ & 0.610 \\
\hline $\begin{array}{c}\text { Did not help me when I had trouble } \\
\text { understanding something }\end{array}$ & $\mathrm{CN} 2$ & 0.794 \\
\hline Did not read books to me & $\mathrm{CN} 3$ & 0.570 \\
\hline $\begin{array}{c}\text { Did not show interest in my grades in } \\
\text { school }\end{array}$ & $\mathrm{CN} 4$ & 0.335 \\
\hline $\begin{array}{c}\text { Did not talk about things in the news } \\
\text { with me }\end{array}$ & $\mathrm{CN} 5$ & 0.642 \\
\hline
\end{tabular}

According to the results shown in Table 7 the scores of each and every respondent for the Cognitive Neglect factor is calculated as follows.

Cognitive Neglect Score $=0.610(\mathrm{CN} 1)+0.794(\mathrm{CN} 2)+$ $0.570(\mathrm{CN} 3)+0.335(\mathrm{CN} 4)+0.642(\mathrm{CN} 5)$

The indicator CN2 is the highly affected indicator for the Cognitive Neglect factor while CN4 is less impacted when considering other indicators. However, each indicator shows a strong effect on the Cognitive Neglect factor.

\section{III.II.IV Score Estimation For Physical Neglect}

Table Viii: Communalities Results Of Confirmatory Factor Analysis For Physical Neglect

\begin{tabular}{|c|c|c|}
\hline Physical Neglect Indicator & ID & Communality \\
\hline $\begin{array}{c}\text { Made sure that I did not see a dentist when } \\
\text { I needed one }\end{array}$ & PN1 & 0.724 \\
\hline Locked me out of the house on purpose & PN2 & 0.618 \\
\hline Made sure that I did not get enough sleep & PN3 & 0.909 \\
\hline Did not give me clean clothes & PN4 & 0.700 \\
\hline Did not give me enough food to eat & PN5 & 0.376 \\
\hline Did not give me enough clothes to keep \\
me warm & PN6 & 0.743 \\
\hline Did not see a doctor when I needed one & PN7 & 0.551 \\
\hline
\end{tabular}

According to the results shown in Table 8 the scores of each respondent for the Physical Neglect factor is calculated.

$$
\begin{aligned}
\text { Physical Neglect Score }=0.724 & (\mathrm{PN} 1)+0.618(\mathrm{PN} 2)+0.909 \\
& (\mathrm{PN} 3)+0.700(\mathrm{PN} 4)+0.376 \\
& (\mathrm{PN} 5)+0.743(\mathrm{PN})+0.551 \\
& (\mathrm{PN})
\end{aligned}
$$

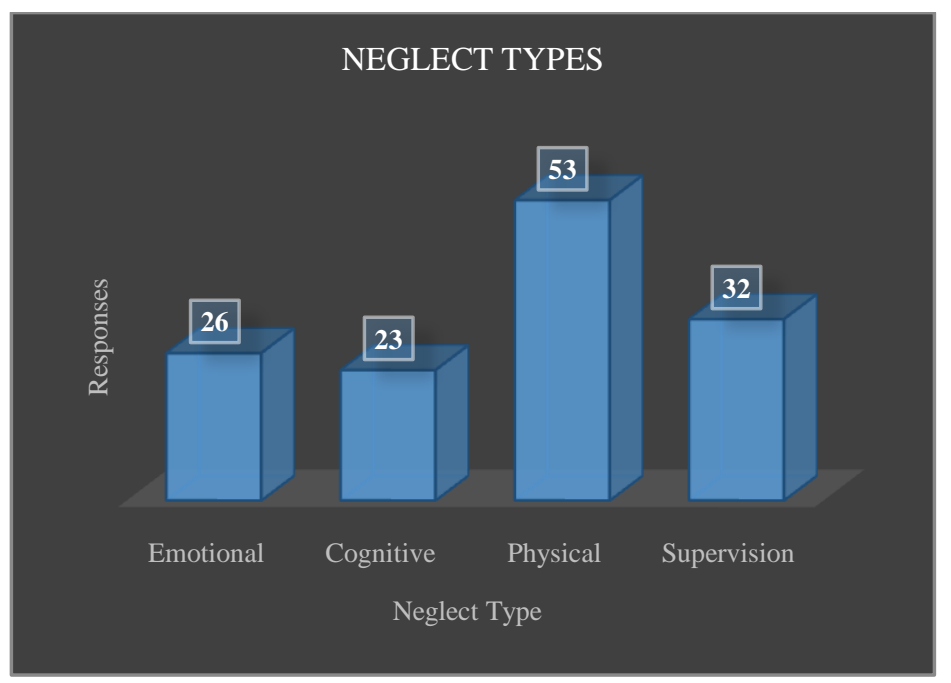

Fig. 1 Neglect Types

The indicator PN3 is the highly affected Physical Neglect factor while PN5 is less impacted when considering other indicators. However, each indicator shows a strong effect on the Physical Neglect factor.

As the figure 4 shows, the physical neglect is the most common type of child neglect and 53 respondents go under this category, while the cognitive neglect type has the lowest respondents. The respondents that go under Supervision, Emotional and Cognitive neglect are 32, 26 and 23 respectively.

\section{DISCUSSION}

The analysis of the 134 questionnaires found that most of the respondents had mentioned that they were victims of physical neglect. Physical neglect is the failure to protect the child from harm or danger and provide the child with basic physical 
needs such as suitable shelter, food, or clothing (Carter \& Myers, as cited in Serasinghe, 2021). Chronic neglect could occur due to the parents with substance abuse problems who do not provide basic needs for their children (Dubowitz, as cited in Klevens, Barnett, Florence, \& Moore, 2015). Therefore, parents with substance abuse could be identified as the chronic neglect, and chronicity could be explained as a pattern of the same acts or omissions that extend over time or repeat over time (Harrington et al., 2002). Current study found that many parents spent money on drugs as they were addicted to, rather than fulfilling their child's necessities. Some of relevant interview statements are as follows,

"After our father left us, my sister and I started hating him. He used to take drugs and had fights with my mother. He used to beat and scold us. He was addicted to drugs and never treated us properly. There were days when we didn't have anything to eat at home because of my father's drug addiction. He spent all his money on drugs. (participant1)"

Lack of foods and appropriate clothes for the child is categorized as nutrition and clothing neglect under the physical neglect respectively. One of the duties of parent or caregiver is to keep the child clean and wash his/her clothes until the child grows up enough to do his work independently. However, some participants had to be engaged their day to day tasks on their own without any support. In fact, sometimes they had to face situations such as washing others' clothes even during their childhood.

"I have to do all my work on my own. I have to do all the household chores like washing others' clothes, cleaning the house, dishes etc., like a servant." (participant 8)

"Before my mother went abroad, she used to cook for us. After she went there, my sister and I cooked taking turns." (participant 1)

Sedlak as cited in Stoltenborgh, (2012) suggest that physical neglect contains the ignorance of physical threats in home, child's security, lacking nutrition, clothing, sanitation and ignorance of the medical treatment for the required condition. Not following up of a child's medical recommendation and in fact, not getting dental care are also considered as medical neglect under the category of physical neglect ( Hadley, 2003 as cited in Diane DePanfilis, 2006).

The interviews identified that most participants (neglected children) lived with a single parent or at their relative's home.

"My father passed away. He died ten years ago. My father used to work in a hotel and he used to eat a lot of oily food and died due to high cholesterol. He never told us his pains, but one day his condition was serious and my mother took him to the hospital. After that he died." (participant 3)

"When I was small, my father and mother had a big fight and my father left home. Now he is staying with his sister. He comes here occasionally. When he was with us, he used to give money for family expenses. Now he gives his earnings to his sister's family." (participant 7)
"My mother is working at a tailor shop. My father passed away due to an accident." (participant 9 )

“My mother is alive, but I don't know exactly where she lives. My father passed away due to the addiction of drugs. When I was born, my father gave me to my grandmother and grandfather to adopt and had instructed them not to tell me that he is my father. Until his, he visited us, but I never knew that he was my father. No one even told me. After his death only, my uncle told me that he was my father. When he died, he was only 24 years old." (participant 10)

According to the above statements, the bond between the child and the parent can be clearly understood. Unfortunately, participants' life stories were full of sorrow. One participant was not aware of her father even though she had interacted with him. It was also found that once the father left home due to family problems, he had never returned. Fathers of some participants had die due to diseases. This shows that the participants were not getting both parents' love continuously in their lives.

"I got to know that she was living in Kelaniya area with my two sisters. I have seen my sisters, but I don't talk with them much. They are married. My mother had left for somewhere else. Now I don't know where she is. I live with my aunt. My mother never cared for me. I don't even like her, because it was my grandparents who looked after me since my childhood. Not my mother. So I don't like her at all." (participant 10)

However, these participants could not get even the minimum facility from their parents or caretakers. Carter and Myers, (2007) specify that a medical doctor may view a parent as neglectful if the parent frequently forgets to give his/her child the prescribed medication, which is considered as the type of neglect. Equally, the parent's or caretaker's rejection or delay in looking for required health care for a child such as denial of health care, delay in health care, the failure to find timely and appropriate medical care for a serious health issue are also considered as the neglect that child has to face from their parents ( Hadley, as cited in Diane DePanfilis, 2006). Some of relevant interview statements are as follows,

"Actually, when I fall sick, no one takes me to the hospital. My aunt gives me tablets which are prescribed for her children's sickness. I don't drink those. I just throw them away thinking that something could happen to me for not drinking medicine. " (participant 8)

"When I fall sick, my aunt takes me to the hospital. While taking me to the hospital she scolds me that I'm a burden to her. She takes me for medication just for the sake of taking me to the hospital, but not because she cares. " (participant 10)

"Even when I fall sick, it is my mother who takes me to the hospital. My father never cared." (participant 2)

On the other hand, sleep is an important factor for every human being. Horne (1988) mentions that sleep is essential for stimulating and reestablishing the physiological process 
that keeps the body and mind healthy to work appropriately. However, most of the respondents mentioned that they have no peace of mind due to the unsecured environment and As a result, they find difficulty in sleeping.

" One day, when I was sleeping, my uncle had come near my bed and tried to touch me. Since then, I never got a proper sleep. I sleep with the fear that my uncle would misbehave. Also, after that incident I never wanted nights to come. Because I'm scared of him. Besides, there are no doors for our bedrooms. So, he could come in at any moment" (participant 8)

"I can't remember a single day when I had proper sleep. I wake up in the midnight and keep thinking about my life. If I sleep, I sleep during day time only. Because my stepfather goes to work at that time and I can sleep peacefully. Besides, when he is at home, he is behind me all the time. Even he goes to work after I go to school only. It's really annoying and disturbs my mind. I hate being at home because of both him and my mother. " (participant 4)

Based on the above statements, it could be identified that several respondents always live with fear as something harmful and negative would occur from their step fathers or uncles to their lives. Besides, the same condition was mentioned by participant 03 and the relevant statement is as follows,

"When I go to bed, I sleep with the fear that uncle would come at any moment and misbehave. From the day that incident happened, I never had a peaceful or proper sleep. Sometimes, I wake up in the middle of the night and start thinking about the problems we have. Then I tear up unknowingly". (participant 3)

The 17 years old girl who was a victim of the abuses including sexual, emotional, physical and neglect indicated trouble in sleeping. As her father is not alive, her mother has to go to work daily. After her mother leaves home, her uncle attempts to abuse her and her sister. Due to these issues, it was found that she could not have a peaceful sleep without any fear. The same condition was stated by participant 08 . In her situation, both parents have neglected the child and the victim's father had given her to one of his relatives in their family for adoption. However, relatives do not treat her appropriately where this child is considered as an orphan.

“When I was five years old, my mother left me. And when I was ten years old, my father left me with my aunt. Now I don't know where my father lives." (participant 8)

“My aunt doesn't like me. She even doesn't want me to study. She always asks for money from me. So, I go for labor work for a payment of Rs.900 per day and whatever I earn, I give it to my aunt." (participant 8)

The relationship with a parent or guardian is highly essential for the child's development. Adler believes that family gathering contributes to the development of personality characteristics (Mueller, 2011). Children in early childhood within their family have greater influence for personality development (Gustafson, 2010). Unfortunately, most participants found a lower level of parental relationship and those conditions also affect their whole behavior including sleep. Likewise, a girl who is 17 years old hates her irresponsible mother for her negligence. As a result, she has to stay with an aunty without her approval.

"Some days I cannot sleep. I think about why my mother ignores me and I automatically start crying the whole night. I'm sad when she doesn't take care of me. (participant 5)"

Based on the above statement, it could be identified that the participant has no peaceful mind to sleep due to her mother. Although she expects love and affection from her mother, mother does not care for her child. Therefore, these experiences could affect her later life and (Polonko, 2006) pointed out that physical neglect has the most severe consequences for children than other types of child abuses.

\section{CONCLUSION}

The literature identifies four major types of child neglect: physical neglect, emotional neglect, supervision neglect, and cognitive neglect (Straus, Murray, Kinard \& Williams, 1997). According to the current study, findings show that physical neglect was the common type of child neglect where several indicators were found to be highly influential. The indicator "Made sure that I did not get enough sleep" was found to be a highly affecting factor for the child's physical neglect. Quantitative findings were similar to qualitative findings. Interview participants mentioned that they had trouble sleeping as they had to live in a less secure environment. Father's drug addiction, mother's carelessness, insufficient income impacted their food consumption. Resulting in frequent hunger among the children. In addition, children were involved in cleaning dishes and washing others' clothes. Parents or guardians had not paid attention when the child needed medical treatments. As a result of that, some children had to take medications prescribed for someone else, when the children were under some medical conditions. Considering this information, it could be concluded that victims of child neglect are more prone to be victims of physical neglect than other categories of child neglect in the Sri Lankan context.

\section{RECOMMENDATION}

Researcher recommend following to the government to address the issues faced by the neglected children and to reduce children being neglected. Government should take necessary action in assigning relevant officers including Child Rights Promoting Officers, Social Workers, Gramasewaka, and active officers for the relevant committees in order to spot children who are neglected from their families. Since respective officers have to work with children, they should have enough knowledge about the children and sensitivity towards their psychological and physical development. Therefore, knowledge capacity enhancement of relevant officers would benefit the child population in the country. 


\section{REFERENCES}

[1] Ben-David, V. (2016). A Focus on Neglect: Comparing the Characteristics of Children and Parents in Cases of Neglect, Abuse, and Non-CAN (Child Abuse and Neglect) in Israeli Rulings on Termination of Parental Rights. Journal of Aggression, Maltreatment and Trauma, 25(7), 721-740. https://doi.org/10.1080/10926771.2016.1153549

[2] Carter, V., \& Myers, M. R. (2007). Exploring the risks of substantiated physical neglect related to poverty and parental characteristics: A national sample. Children and Youth Services Review, 29(1), 110-121. https://doi.org/10.1016/j.childyouth.2006.08.002

[3] Child Welfare Information Gateway. (2011). Definitions of Child Abuse and Neglect. State Statutes, 2010(June), 92.

[4] Cort, N. A., Toth, S. L., Cerulli, C., Rogosch, F., Cort, N. A., Toth, S. L., ... Toth, S. L. (2011). Maternal Intergenerational Transmission of Childhood Multitype Maltreatment Maternal Intergenerational Transmission of Childhood Multitype Maltreatment.

6771. https://doi.org/10.1080/10926771.2011.537740

[5] Diane DePanfilis. (2006). CHILD ABUSE AND NEGLECT Child Neglect: A Guide for Prevention, Asses s ment and Intervention Child Neglect: A Guide for Prevention, Assessment, and. U.S. Department of Health and Human Services Administration.

[6] Gustafson, C. (2010). The Effects of Birth Order on Personality. $39 . \quad$ Retrieved from http://alfredadler.edu/sites/default/files/Gustafson MP 2010.pdf

[7] Harrington, D., \& Ting, L. (2002). The Neglect Scale: Confirmatory Factor Analyses in a Low-Income Sample The Neglect Scale: Confirmatory Factor Analyses in a Low-Income Sample. (May 2014). https://doi.org/10.1177/107755902237266

[8] Harrington, D., Zuravin, S., Depanfilis, D., Ting, L., \& Dubowitz, H. (2002). The Neglect Scale: Confirmatory Factor Analyses in a Low-Income Sample. Child Maltreatment, 7(4), 359-368. https://doi.org/10.1177/107755902237266

[9] Horne, J. A. (1988). Sleep loss and "divergent" thinking ability. Sleep, 11(6), 528-536. https://doi.org/10.1093/sleep/11.6.528
[10] Klevens, J., Barnett, S. B. L., Florence, C., \& Moore, D. W. (2015). Exploring policies for the reduction of child physical abuse and neglect. Child Abuse and Neglect, 40, 1-11. https://doi.org/10.1016/j.chiabu.2014.07.013

[11] Mueller, D. K. (2011). Pampered Children and the Impact of Parenting Styles. (October).

[12] National Child Protection Authority of Sri Lanka. (2019). Functions of the NCPA http://www.childprotection.gov.lk/functions.htm

[13] Parkinson, S., Bromfield, L., Mcdougall, S., \& Salveron, M. (2017). Child Neglect: Key Concepts and Risk Factors a Report To the Nsw Department of Family and Community Services Office of the Senior Practitioner 2017. 1-47. Retrieved from http://www.unisa.edu.au/Global/EASS/Research/ACCP/Child Neglect,Key concept and risk factors report.pdf

[14] Polonko, K. A. (2006). Exploring assumptions about child neglect in relation to the broader field of child maltreatment. Journal of Health and Human Services Administration, 29(3), 260-284.

[15] Putnam, F. W. (2001). Ten-Year Research Update Review: Child Sexual Abuse. 2000, 269-278. https://doi.org/10.1097/01.CHI.0000037029.04952.72

[16] Seneviratne, D., Researcher, I., \& Silva, N. De. (2014). Child Rights Baseline 2009 To Support the Realizing Child Rights Thematic Programme Plan.

[17] Serasinghe, H. P. (2021). The Impact of Poverty for the Child Neglection. American Research Journal of Humanities Social Science (ARJHSS), Volume-04,(08), 38-41.

[18] Stoltenborgh, M. (2012). It should not hurt to be a child: prevalence of child maltreatment across the globe. Retrieved from https://openaccess.leidenuniv.nl/handle/1887/19142

[19] Straus, Murray A.; Kinard, E. Milling; Williams, L. M. (1997). E . Milling Kinard.

[20] Upali, P., \& Fonseka, E. G. (2017). Avenues: Peace, Reconciliation and Development.

[21] Wilkinson, J. (2017). The impacts of abuse and neglect on children; and comparison of different placement options. (March). 